\title{
CONSUMER ATTITUDE AND SENSORY EVALUATION OF MARSHMALLOW
}

\author{
Eva Ungure, Evita Straumite, Sandra Muižniece-Brasava, and Lija Dukalıska
}

Faculty of Food Technology, Latvia University of Agriculture, Jelgava, LV-3001, LATVIA;

eva.ungure@gmail.com; evita.straumite@Ilu.Iv; sandra.muizniece@ Ilu.Iv; lija.dukalska@Ilu.Iv

Communicated by Daina Kārkliṇa

\begin{abstract}
Marshmallow is sugar-candy with foam-like structure. Many studies have revealed the high nutritional value of bee pollen. Due to the nutritional composition of pollen, and according to nonscientific studies, dried bee pollen has been used as an additive in human diets, which provides a well-being sensation and contributes to functional and harmonious balance of the body. Sensory evaluation and market research are an important part of developing a new product. The research was aimed to clarify the situation in the Latvian market, to summarise Latvian consumer attitude on marshmallow, and to determine the sensory properties and quality of marshmallows with bee pollen. A questionnaire was developed - 900 respondents answered questions about their consumption patterns, opinions on quality indices, and possible types of marshmallow packaging. Marshmallow was enriched with three different pollen concentrations: 1.0; 1.5 and 2.5\%. Sensory evaluation was carried out to estimate the optimal concentration of bee pollen that which should be added to marshmallow. Sensory evaluation of experimental marshmallow was characterised by using a 9-point hedonic scale (determination degree of liking). The obtained results showed that consumers liked the marshmallow with $1.5 \%$ bee pollen best of all.
\end{abstract}

Key words: marshmallow, bee pollen, sensory evaluation, consumer attitude.

\section{INTRODUCTION}

The meaning of the term 'confectionery' is different in every country and may cover a very large amount of different products manufactured in various manners. Chocolate confectioneries include bars, blocks, and bonbons, and sugar confectionery encompasses boiled sweets, toffees, fudge, fondants, jellies, and pastilles. Confectionery goods are a very heterogeneous group of products made with milk powder and other dairy products; cocoa and chocolate products; sugar, honey, syrups or sweeteners; nuts, fruits or jams; starches, gelatine, pectin or other thickeners; egg albumen; spices, colours, flavours or acidulates (Cakebread, 1975; Konkel, 2001; Vaclavik and Christian, 2008; Kawo and Abdulmumin, 2009).

The confectionery industry is enormous, ranging from small shops to branches of the largest companies in the food industry. The sweets are divided into three classes: chocolate, flour and sugar confectionery (Manley, 1998; Quinton and Kennedy, 2002). Sugar confectionery has been developed over the centuries with increasing sophistication, and it exists in countless formats with different degrees of sweetness, flavours and aromas, textures and mouth feel. Confectionery serves a very simple purpose; the rush of sweetness coupled with pleasant flavours, and aromas. The feeling in the mouth provokes almost instantaneous feeling of well-being and happiness. Sugar confectionery includes by definition products that contain predominantly one form or another of the following sugars: sucrose (usually cane or beet sugar); dextrose (otherwise known as glucose, usually corn sugar); fructose (often refered to fruit sugar) or lactose (otherwise known as milk sugar) (Zumbé et al., 2001).

The specific kind of confectioneries considered here has foam-like structures (marshmallows, soufflés, and nougats). Marshmallows are simply described as air bubbles surrounded by sugar syrup. The sugar syrup, made of sucrose, corn syrup, and water, is cooked at appropriate temperature to reach the desired water content, which allows air to be whipped into the matrix by mechanical agitation. Proteins, such as gelatine, gum Arabic, egg albumen, agar-agar, pectin, milk or soy protein, are typically added to the sugar syrup to stabilise the foam. During whipping, the density of the product decreases as the syrup and foam mixture expands into a light, fluffy marshmallow. Marshmallows may be either non-grained or grained crystal aggregate, depending on the ratio of sucrose to corn syrup (Sucharzewska et al., 2003; Ergun et al., 2010). Certain glassy sugars tend to be hygroscopic, rapidly picking up moisture from the air, which causes significant changes that lead to the end of shelf life. These products need to be protected from moisture uptake during storage (Ergun et al., 2010). 
The aim of quality properties is to provide a safe, inoffensive, as well as nutritionally rich food. Pollen is important in bee life cycle, and it is understandable that people's interest in its composition and applicability as a dietary supplement is high (Graikou et al., 2011; Feás et al., 2012).

Bee honey has been used by man since the beginning of humanity. Although this is the most common beehive product, there are other goods, such as bee pollen, royal jelly, propolis and beeswax. These natural goods are well appreciated by consumers due to the high number of quality checks they go through, as well as for their dietetic and therapeutic qualities. The major components of bee pollen are carbohydrates, crude fibres, proteins and lipids at proportions ranging between 13 and 55\%, 0.3 and 20\%, 10 and 40\%, 1 and $10 \%$, respectively. Other minor components are minerals and trace elements, vitamins and carotenoids, phenolic compounds, flavonoids, sterols and terpens. In fact, bee pollen is referred to as the "only perfectly complete food", since it contains all the essential amino acids needed for the human organism (Silva et al., 2005; Carpes et al., 2009; Le Blanc et al., 2009; Graikou et al., 2011; Feás et al., 2012).

Since in a healthy diet sweets are allocated less than $5 \%$ of the daily food consumption, they must be high quality in every respect and attractive for consumers. Enriching sugar confectionery with pollen would supplement the diet with biologically active substances.

The formulation and marketing of consumer products today have become very complex operations in which both sensory testing and market research have important parts to play. Both disciplines are united by a common goal to produce goods with an optimum combination of product attributes, compatible with manufacturing costs that will sell successfully and profitably in the market place. Despite of this common goal, the different requirements of technical and marketing personnel have led to the separation and interaction between the two disciplines. There are, however, techniques and approaches used by both the sensory and market researcher, which when combined, can offer improved product testing (Wilton and Greenhoff, 1988; Moskowitz et al., 2006).

Food choice is not determined solely by the perceived properties of a foodstuff. It depends on personal attitude towards the attributes a product possesses. Consumer responses are vital in the development of a product if it is to compete successfully in the market place (Frances and Piggott, 1991-1992). There is a wide variety of market research procedures that could be used to elicit information about product attributes, and to measure attitudes and beliefs. These include unstructured spontaneous techniques, such as interviews and projective methods, and also highly structured methods, such as dissimilarity scaling where appropriate statistical procedures are used to obtain product spaces (maps) and identify salient product dimensions (McEwan and Thomson, 1989).
Sensory evaluation techniques are frequently used; however, applied sensory is most often used within the private industry. Basic sensory techniques can be an invaluable aid to research on nutritional or functional benefits of natural products, such as whole fruits, nuts and vegetables (through varietal selection, breeding, (etc.) in addition to clinical trials of botanicals). As part of the effort to discover, develop and market healthier products, understanding nutritional and functional benefits is a key aspect. Of additional importance is highlighting and refining the products' sensory properties in an attempt to ultimately appeal to consumers: no matter how healthy and nutritious a food is, if it does not appeal to its intended end user, it is unlikely to succeed in today's marketplace (Civille and Oftedal, 2012).

The aim of this study was to determine the Latvian consumer attitude on marshmallow packaging presentation, and the potential marshmallow market expandability. Furthermore, sensory evaluation was carried out to estimate the degree of liking of pollen-rich marshmallow and to determine the optimal desired pollen concentration.

\section{MATERIALS AND METHODS}

The research was aimed to assess consumer attitude to marshmallow as well as its quality. The study was organized in two stages:

1. A consumer questionnaire was developed to analyze the situation in the Latvian market and to determine Latvian consumer attitude concerning their consumption patterns, opinion on quality indices, and possible packaging types of marshmallows. The questionnaire was used as a basic tool, which consisted of ten questions answered by consumers. Respondents were asked to answer both multiple-choices and open-type questions. The survey was designed using website www.visidati.lv, which gives an opportunity to obtain a quick and effective survey distribution and data collection. In order to obtain a link between the average population answers and the web-based questionnaire, it was also sent to people. The data consisted of the answers of all 900 respondents who completed questionnaires.

2. Experiments were performed in the International Food exhibition "Riga Food 2011", to assess the degree of liking and optimal desired pollen in marshmallow. Consumers evaluated the degree of liking of marshmallow samples that had additions of $1.0,1.5$ and $2.5 \%$ bee pollen. The control sample was marshmallow without bee pollen. The marshmallow used consisted of: sugar, glucose syrup, water, apple puree (apple, preservatives E202, E211), gelling agent - pectin, protein powder, acidity regulator - lactic acid, bulking — sodium lactate, and vanillin $(0.05 \%)$. The 9point hedonic scale (9, extremely like, 5 , neither like nor dislike, and 1, extremely dislike) method was used based on ISO 4121:2003 "Sensory analysis — Guidelines for the use of quantitative response scales". One hundred and thirty consumers (age 14 to 66 years) were involved in the evaluation. 


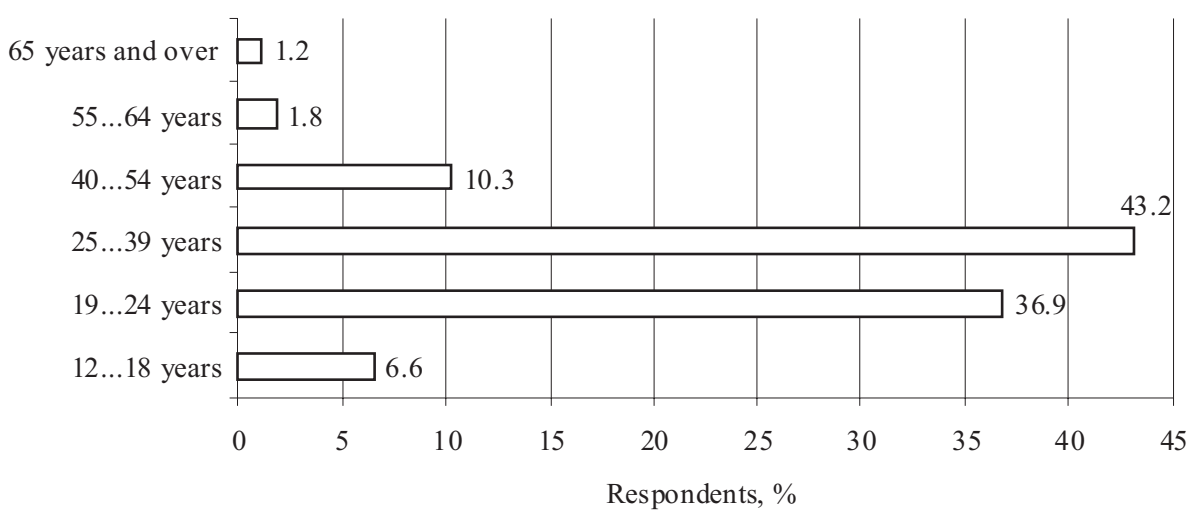

Fig. 1. Respondent division according to age, $\%$.

Most respondents were up to 40 years, who were also considered as the main body of consumers who were likely to consume marshmallow (Fig. 1).

The test results were processed using software SPSS package 16. $P$ value 0.05 was considered as a significant difference. One-way and two-way factor analysis of variance (ANOVA) as well the Tukey's test were used to test for significant differences.

\section{RESULTS}

The 900 respondents ( $28 \%$ men and $72 \%$ women) answered ten questions regarding how well-recognized is marshmallow, and the main features for this kind of sweets for choice by consumers. One of most important questions was to understand the consumer opinion about sweets, mainly the type of marshmallow packaging for marketing, and the market turnover. Respondents were asked to evaluate the consumer demand for marshmallow, likeness and the packaging options. Of the ten questions associated to the product (marshmallow), two were aimed to obtain basic information about the consumer.

All 900 respondents liked marshmallow. The majority (96\%) of consumers asserted that marshmallow is tasty, and $4 \%$ of respondents considered this product as unpalatable and too sugary; some consumers did not like the structure of marshmallow.

According to frequency of purchase of marshmallow (Fig. 2), $35 \%$ of respondents infrequently purchased marshmallow, $17.4 \%$ — at least once a week, $46.8 \%$ — monthly and
$0.8 \%$ admitted they did not routinely use marshmallow, but consumed this sweet when available as a treat.

The respondents mentioned that they purchased marshmallow in various cases (Fig. 3). The majority favoured buying marshmallow daily, indicating a demand for fresh marshmallow in small appropriate packaging for purchase as a frequently used sweet. The majority of consumers (586) considered that they would like to choose marshmallow for a gift or social evening (234).

Subsequent questions on the product were aimed to evaluate respondent opinion about the packaging style as well as on how the packaging design influences the choice of product in the market. Most respondents admitted that both style and the manner how the product is offered to the costumer in the retail sector are important (Fig. 4).

An important consumer opinion was on the amount of marshmallow in one package (Fig. 5). It is determined that the optimal amount for most of people (35.1\% to $45.4 \%$ ) was two to four pieces in one package.

A sensory evaluation was performed to determine the optimal bee pollen addition to marshmallow raw material mass, (Fig. 6). ANOVA indicated significant difference between concentrations of bee pollen used $(P>0.05)$. The Tukey's test was used to test for differences between preference of the marshmallow samples. The analysis showed significant difference $(P>0.05)$ in the degree of liking between the control sample and samples with pollen A (1.0\%) and C $(2.5 \%)$. Consumers recognised the marshmallow sample with $2.5 \%$ bee pollen as having a too typical taste, sharp af-

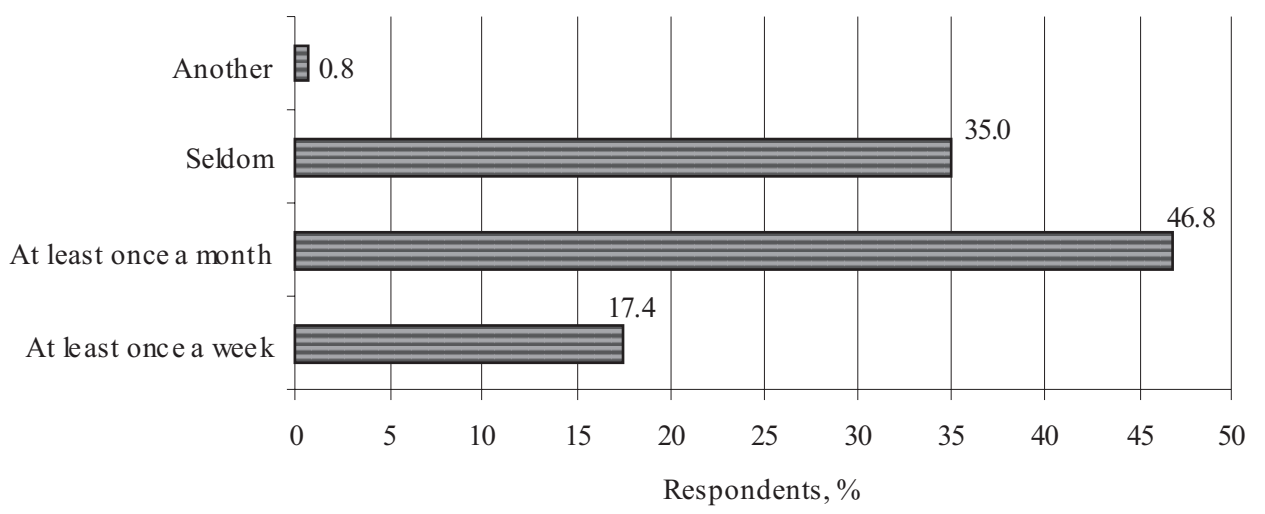

Fig. 2. Purchasing frequency of marshmallow, \%. 

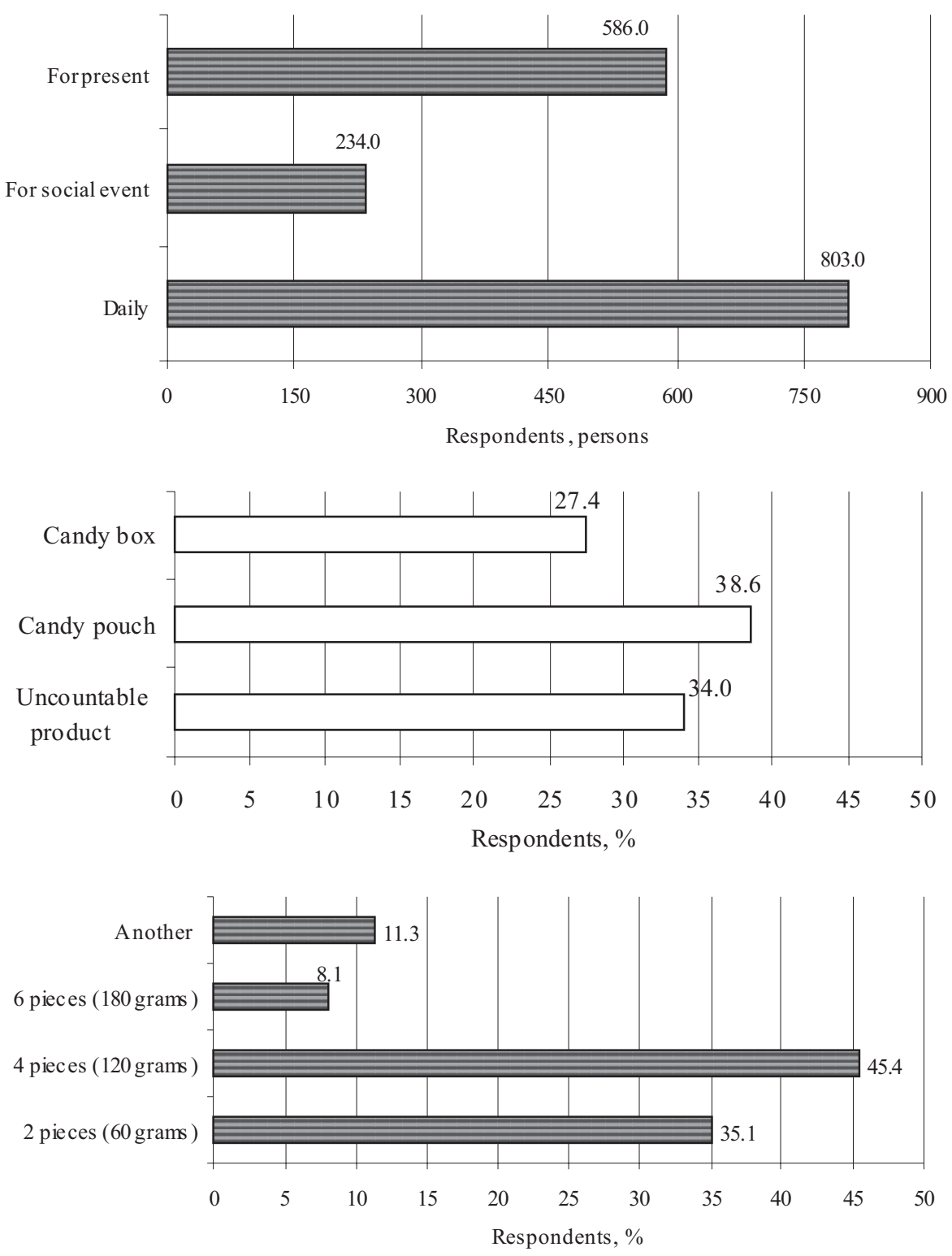

Fig. 3. Purchase intent of marshmallow.

Fig. 4. The choice of marshmallow purchasing style, $\%$.

Fig. 5. Consumer view on the optimum marshmallow quantity (pieces) in one package.

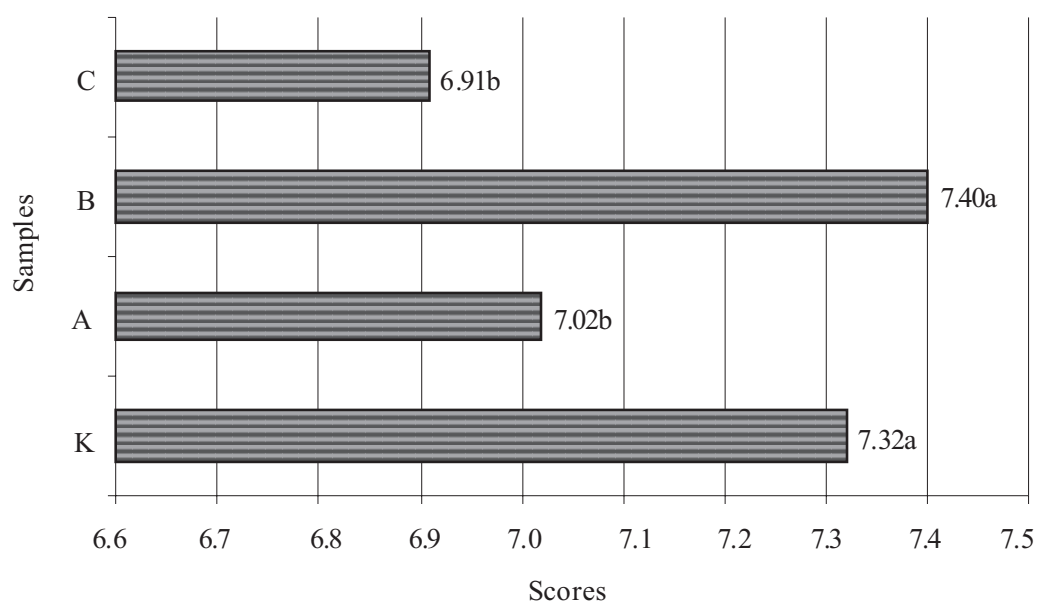

Fig. 6. Evaluation results of marshmallow with bee pollen using 9-point hedonic scale.

$\mathbf{K}$ - marshmallow without pollen (control); $\mathbf{A}$ - marshmallow with $1.0 \%$ pollen addition; $\mathbf{B}$ - marshmallow with $1.5 \%$ pollen addition; $\mathbf{C}$ - marshmallow with $2.5 \%$ pollen addition.

*Values, marked with the same letters, are not significantly different $(P>0.05)$.

tertaste, and a not so airy structure. Significant differences also were found between $\mathrm{B}$ and $\mathrm{A}$, and between $\mathrm{B}$ and $\mathrm{C}$ $(P>0.05)$, in liking degree. Results of the hedonic scores showed that the panellists most liked samples K (control) and B (with $1.5 \%$ bee pollen), and there was no significant difference beween these $(P>0.05)$. Thus, the consumer preferred both the classical marshmallow with vanilla, and with bee pollen $(1.5 \%)$ enriched marshmallow. 


\section{DISCUSSION}

The European confectionery market grew at a fairly steady rate during the period 2005-2009, as a result of steady sales growth in the chocolate category. Although the overall market growth is expected to decelerate slightly in the forecast period, the annual rate of growth is set to rise from a low of $2.5 \%$ in 2009 to a high of $2.9 \%$ in 2014 . Chocolate in 2009 is the largest segment of the confectionery market in Europe, accounting for $51.7 \%$ of the market's total value. The sugar confectionery segment accounts for a further $34.6 \%$, gum $11.1 \%$ and cereals bars $2.6 \%$ of the market (Anonymous, 2010).

In Europe, the main distribution channels for the confectionery market are supermarkets and hypermarkets (30.4\%), independet retailers $(26.5 \%)$, convenience stores $(21.4 \%)$ and other of the market value (21.7\%) (Anonymous, 2010). Supermarket chains are often able to negotiate very strongly on price with confectionery producers; this boosts their buyer power significantly. An increasing number of product lines have been developed to create healthier alternatives to their existing lines, with substitute versions offering no artificial colours, low sugar, as well as the inclusion of additives such as ingredients with high nutrition value.

The leading players in the Eastern European confectionery market include Mars, Inc. (14.3\%), The United Confectionary Manufacturers management company and Nestle S.A. (8.9\%), Cadbury plc (8.6\%) and others - 68.3\%. In Latvia the leading players are GmbH Laima, Ltd Skriveru saldumi, Ltd Pure Chocolate and Ltd Bona Dea. The largest marshmallow manufacturer in Latvia is GmbH Laima, however, other manufacturers, like Ltd. Bona Dea, Ltd. Mikas M, as well as importers from Russia and Lithuania are coming into the market.

The Latvian consumer survey results showed that the amount of choice sweets in a package strongly affect whether they are purchased daily. Often in proposed packagings the amount of sweets is too large. This suggests that a purchasing manner could be goods sold by weight, but in this case the quality of product often does not conform to consumer wishes. Marshmallows packed in boxes usually are chosen as gifts, since they are too expensive for daily consumption. Consumers normally purchase marshmallows in simple polypropylene (PP) pouch packaging. The respondents suggested that they would like to buy marshmallows packed as one piece in a pouch, as this could provide a good solution for a replacement of small chocolate bars or candy packs. This kind of supply on the market could present good opportunities for sales concerning coffee breaks during conferences and other public activities.

Further questions were given to determine respondent reaction to the wide assortment of marshmallows in the market. There are several marshmallow forms currently in retail: traditional (with vanilla), covered with chocolate layer or glazed, as well as marshmallow refined with various additions, like strawberries, apricots, condensed milk, or cappuccino. Most respondents $(97 \%)$ had noticed the high diversity of marshmallow in the market, but $3 \%$ of respondents did not pay attention to new products in the retail. $69 \%$ of respondents preferred marshmallows with additions, while $31.4 \%$ preferred traditional vanilla marshmallow (Fig. 5). Marshmallow flavour needs to follow the market demand and trends.

Much research has been carried out that has revealed high nutritional value of bee pollen. Considering pollen nutritional composition and according to non-scientific studies, dried bee pollen used as food in human diets provides a sense of well-being and contributes to functional and harmonious balance of the body. Confectionery products are usually selected for consumption based upon flavour and textural properties and are often considered as sources of fats and carbohydrates (Grembecka and Szefer, 2012). By enriching sugar confectionery with pollen, it would be possible to supplement the diet with biologically active substances. Increased competition and new opportunities stimulated by progressively vanishing trade barriers and expanding world markets have greatly accelerated the food industry's world-wide requirement for new products, quality improvements and extended shelf-life (Sidel and Stone, 1993). The survey data and consumer attitude towards bee products (marshmallow with 1.0, 1.5 and $2.5 \%$ bee pollen) can be used to determine preferences. Traditional marshmallow without pollen was used as a control. The marshmallow enriched with $1.5 \%$ bee pollen had an agreeable bee pollen taste, aftertaste and aroma. This indicated that the optimal bee pollen concentration for further experiments should be $1.5 \%$. Regarding willingness to buy, most of the respondents $(91.9 \%)$ after testing considered that they would buy this product as interesting. However, $8.1 \%$ of respondents had a dislike to the new product, because they did not like honey and bee pollen taste, and they would not choose any product with this taste. Since about $92 \%$ of the respondents considered marshmallow with $1.5 \%$ bee pollen as tasty and with a pleasant pollen taste and aftertaste, it can be expected that the new product would take a certain niche of the market.

The conclusions are:

- Latvian consumers recognise marshmallow, sugar-candy with foam-like structure. It is purchased every day and in social events. The data showed that consumer choice is affected by the type of packaging and the variety of flavours. For everyday use, consumers would prefer smaller package size. Consumers admitted that they would like to see a new product with pollen rich marshmallow on the market.

- The results of sensory evaluation demonstrated that there was no significant difference between the control sample (marshmallow without bee pollen) and the marshmallow sample with $1.5 \%$ bee pollen $(P>0.05)$. 


\section{ACKNOWLEDGEMENTS}

The research was supported by the ESF "Support for doctoral studies in LLU", Contract

No. 2009/0180/1DP/1.1.2.1.2./09/IPIA/VIAA/017.

\section{REFERENCES}

Anonymous (2010). Confectionery in Europe. Industry profile. Datamonitor, references code: 0201-0710, pp. 1-36 (last accessed 28 May 2012, from www.docin.com/p-288623130.html).

Cakebread, S. (1975). Sugar and Chocolate Confectionery. Oxford: Oxford University Press. 60 pp.

Carpes, S. T., Mourao, G. B., Alencar, S. M., Masson, M. L. (2009). Chemical composition and free radical scavenging activity of Apis mellifera bee pollen from Southern Brazil. Brazil. J. Food Technol., 12 (3), 220-229.

Civille, G. V., Oftedal, K. N.. (2012). Sensory evaluation techniques Make "good for you" taste "good". Physiol. Behav., 107 (4), 598-605

Ergun, R., Lietha, R., Hartel, R. W. (2010). Moisture and shelf life in sugar confections. Crit. Rev. Food Sci. Nutr., 50 (2), 162-192.

Feás, X., Vázquez-Tato, M. P., Estevinho, L., Seijas, J. A., Iglesias, A. (2012). Organic bee pollen: Botanical origin, nutritional value, bioactive compounds, antioxidant activity and microbiological quality. Molecules, 17 (7), 8359-8377.

Frances, R. J., Piggott, J. R. (1991-1992) Free choice profiling in consumer research. Food Quality Pref., 3 (3), 129-134.

Graikou, K., Kapeta, S., Aligiannis, N., Sotiroudis, G., Chondrogianni, N., Gonos, E., Chinou, I. (2011). Chemical analysis of Greek pollen - antioxidant, antimicrobial and proteasome activation properties. Chem. Centr. J., 5 (1), 33, 1-9.

Grembecka, M., Szefer, P. (2012). Differentiation of confectionery products based on mineral composition. Food Anal. Meth., 5 (2), 250-259.

Kawo, A. H., Abdulmumin, F. N. (2009). Microbiological quality of re-packaged sweets sold in metropolitan Kano, Nigeria. Bayero J. Pure Appl. Sci., 2 (1), 154-159.
Konkel, P. J. (2001) Confectionery products. In: Downes, F. P., Ito, K. (eds.). Compendium of Methods for the Microbiological Examination of Foods (4 ${ }^{\text {th }}$ edn.) (pp. 555-561). Washington: American PublicHealth Association.

Le Blanc, B. W., Davis, O. K., Boue, S., Delucca, A., Deeby, T. A. (2009). Antioxidant activity of Sonoran Desert bee pollen. Food Chem., 115 (4), 1299-1305.

Manley, D. (1998). Biscuit, Cookie and Cracker Manufacturing: Manual 1 Ingredients. D. Cambridge, UK: Woodhad Publishing Limited, 82 pp.

McEwan, J. A., Thomson, D. M. H. (1989). The repertory grid method and preference mapping in market research: A case study on chocolate confectionery. Food Quality Prefer., 1 (2), 59-68.

Moskowitz, H. R., Beckley, J. H., Resurreccion, A. V. A. (2006). Sensory and consumer research in food product design and development. Oxford: Blackwell Publishing. 358 p.

Quinton, L. A., Kennedy, J. F. (2002). Book review: The Science of Sugar Confectionery: W.P. Edwards, The Royal Society of Chemistry, 2000. Carbohydr. Polym., 47 (1), 88-89.

Sidel, J. L., Stone, H. (1993). The role of sensory evaluation in the food industry. Food Quality Prefer., 4 (1-2), 65-73.

Silva, T. M. S., Camara, C. A., Lins, A. C. S., Barbosa-Filho, J. M., Da Silva, E. M. S., Freitas, B. M., Santos, F. A. R. (2005). Chemical composition and free radical scavenging activity of pollen load from stingless bee Milipona subnitida Ducke. J. Food Compos. Anal., 19, 507-511.

Sucharzewska, D., Stochmal, A., Oleszek, W. (2003). The effect of Yucca schidigera extract on the physical structure and on the oxidative stability of sugar-candy foam products. Lebensmit. Wiss. Technol., 36 (3), 347-351.

Vaclavik, V. A., Christian, E. W. (2008). Sugar sweeteners, and confections. In: Essentials of Food Science. $3^{\text {rd }}$ edn. (pp. 331-348). New York: Springer Science+Business Media, LLC.

Wilton, V., Greenhoff, K. (1988). Integration of sensory techniques into market research. Food Quality Prefer., 1 (1), 33-35.

Zumbé, A., Lee, A., Storey, D. (2001). Polyols in confectionery: the route to sugar-free, reduced sugar and reduced calorie confectionery. Brit. J. Nutr., $\mathbf{8 5}, 31-45$.

Received 24 September 2012

\section{ZEFİRU SENSORĀ VĒRTĒŠANA UN PATĒRĒTĀJU ATTIEKSME}

Sensorai vērtēšanai un tirgus izpētei ir liela nozīme jaunu produktu izstrādē. Lai arī zefīrs Latvijas tirgū ir pieejams sen, tomēr arvien ir novērojamas tendences šī produkta bagātināšanai ar dažādām piedevām. Zinātniskajā literatūrā atspoguḷoti pētījumu, kas parāda ziedputekšṇu augsto uzturvērtîbu, līdz ar to ir saprotama cilvēku interese par to sastāvu un izmantošanas iespējām uztura papildināšanai un pilnveidošanai. Pētījuma mērḳis ir noskaidrot situāciju Latvijas tirgū, izvērtēt patērētāju informētību par zefìru, tā pieprasījumu, optimālo iepakojuma daudzumu un tā noformējumu, kā arī veikt sensoro vērtēšanu ar ziedputekšniem bagātinātam zefïram. Anketēšana veikta interneta vietnē www.visidati.lv. Kopumā aptaujāti 900 respondenti (28\% vīrieši un $72 \%$ sievietes). Lai noskaidrotu potenciālo patērētāju viedokli, ar ziedputekšņiem bagātināts zefîrs vērtēts Starptautiskajā pārtikas izstādē „,Riga Food 2011”. Vērtēšanā piedalījās 130 izstādes apmeklētāji. Sensori pēc hedoniskās skalas novērtēts zefīrs ar dažādu ziedputekšn̨u koncentrāciju (1, 2 un 2.5\%). Lai noteiktu paraugu patikšanas pakāpi (ISO 4121:2003), izmantota 9 punktu hedoniskā skala (9 - ārkārtīgi patīk, 1 - ārkārtīgi nepatīk). Pēc sensorās vērtēšanas rezultātiem var secināt, ka patērētājiem vislabāk patīk kontroles paraugs (klasiskais zefïrs) un zefīrs ar 1,5\% ziedputekšniem, starp tiem patikšanas zinā nepastāv būtiska atškirība $(P<0,05)$. Tas liecina, ka patērētājiem vienlīdz labi patīk gan klasiskais zefìrs, gan ar ziedputekšniem bagātināts $(1,5 \%)$ zefïrs. 